\title{
Thermal Effects of the Proposed Water Reclamation Centre Discharge on the East Holland River
}

\author{
Hailiang Shen, Juraj Cunderlik, George Godin, Adrian Coombs, Alan Rimer and Ian Dobrindt
}

\begin{abstract}
The Innovative Wastewater Treatment Technologies alternative was confirmed as the preferred alternative for accommodating the growth forecasted to occur in the Upper York Sewage Solutions (UYSS) service area to 2031 in portions of the Regional Municipality of York (York Region). A key element of the UYSS Environmental Assessment (EA) was the influence of the treated water discharge from the proposed Water Reclamation Centre (WRC) on the East Holland River and its thermal regime. The purpose of this study, conducted as part of the EA, was to examine potential thermal benefits and impacts of the WRC discharge on the East Holland River. The potential effects of the WRC discharge were evaluated by utilizing Environmental Fluid Dynamics Code (EFDC) for assessing water temperature effects and Army Corps of Engineers' Quality-Width 2D (CE-QUAL-W2) for assessing ice effects. The EFDC model predicts that the WRC discharge will increase water temperature during winter and decrease during summer; the CE-QUAL-W2 model predicts the ice thickness will decrease during winter periods. The areas near the discharge location will experience the largest water temperature change and ice thickness decrease, and the effects on water temperature and ice thickness will gradually diminish downstream of the discharge location.
\end{abstract}

Keywords: discharge, York Region, environmental assessment, EFDC, CE-QUAL-W2.

\section{Introduction}

The Innovative Wastewater Treatment Technologies alternative (also referred to as the Lake Simcoe Water Reclamation Centre Alternative) was confirmed as the preferred alternative for accommodating the growth forecasted to occur in the Upper York Sewage Solutions (UYSS) service area to 2031 in portions of the Regional Municipality of York (York Region). A key element of the UYSS Environmental Assessment (UYSSEA) was the influence of the treated water discharge from the proposed Water Reclamation Centre (WRC) on the East Holland River and its thermal regime. The purpose of this study, conducted as part of the EA, was to examine potential thermal benefits and impacts of the WRC discharge on the East Holland River.

The potential effects of the WRC discharge were evaluated by utilizing an advanced dynamic numerical modelling approach. Thermal and river ice hydrodynamic models were built for the study area and the effects of the WRC discharge were evaluated by comparing the results of the models generated by scenarios without and with the WRC discharge. The Environmental Fluid Dynamics Code (EFDC) model was used to evaluate water temperature effects in the river, and the U.S. Army Corps of Engineers' Quality-Width 2D (CE-QUAL-W2, Cole and Wells 2011) model was used to evaluate the river ice effects. River bathymetry was compiled in ArcGIS from various survey datasets. For the areas with no survey data, an interpolation algorithm was developed using Visual Basic for Applications (VBA)/ArcObjects.
The modelling results suggest that water temperatures in the East Holland River near the discharge location will increase during the winter period and decrease during the summer period. The WRC discharge will provide a moderating effect on water temperatures during the summer low flow, high temperature receiver conditions. Ice thickness in the River near the discharge location is modelled to decrease during the winter period. The changes in ice thickness will depend on atmospheric conditions; and will be more pronounced during mild winters. The effect of the WRC discharge will gradually diminish downstream of the discharge location. The affected section of the River will extend from the discharge location to the confluence with the West Holland River. Downstream of the confluence the effect of the WRC discharge will be minimal.

\section{Background}

In March 2010, the Ontario Minister of the Environment approved the Terms of Reference for the UYSS EA, with an amendment to consider innovative wastewater treatment technologies as part of the assessment. In response, the Regional Municipality of York (York Region) developed the Lake Simcoe WRC Alternative.

In this alternative, wastewater resulting from approved growth in the Town of Aurora and most of the Town of Newmarket would be conveyed through the existing York Durham Sewage System (YDSS) for treatment at the Duffin Creek Water Pollution Control Plant (WPCP) and discharge to Lake Ontario.

Shen, H., J. Cunderlik, G. Godin, A. Coombs, A. Rimer and I. Dobrindt. 2014. "Thermal Effects of the Proposed Water Reclamation Centre Discharge on the East Holland River." Journal of Water Management Modeling C366. doi: 10.14796/JWMM.C366.

(c) CHI 2014 www.chijournal.org ISSN: 2292-6062 
To accommodate this, modifications to the existing YDSS in the Town of Newmarket would be required. Wastewater from approved growth in the Town of East Gwillimbury and the remaining portion of the Town of Newmarket would be conveyed to the proposed WRC for treatment, using environmentally sustainable wastewater purification and water recycling technologies, and the treated water would be discharged to the East Holland River within the Lake Simcoe watershed.

The Lake Simcoe WRC will treat wastewater using proven, leading-edge wastewater purification and water recycling technologies to produce two types of reclaimed water:

- nutrient-rich water for potential applications such as irrigation and industrial uses; and

- high quality, phosphorus reduced water for discharge to the East Holland River within the Lake Simcoe watershed.

The Lake Simcoe WRC Alternative was selected as the preferred Alternative To the Undertaking. As a result, a series of studies was prepared to provide detailed evaluations of the receiver and the WRC discharge requirements as part of the Alternative Methods of Carrying out the Undertaking stage of the UYSS EA.

This paper summarizes the results of a detailed study of the potential thermal effects of the WRC discharge on the East Holland River. The main objectives of the study were to investigate the effects of the WRC discharge on the thermal regime of the East Holland River, and to study the effects of the WRC discharge on the river ice regime in the East Holland River.

\section{Study Area}

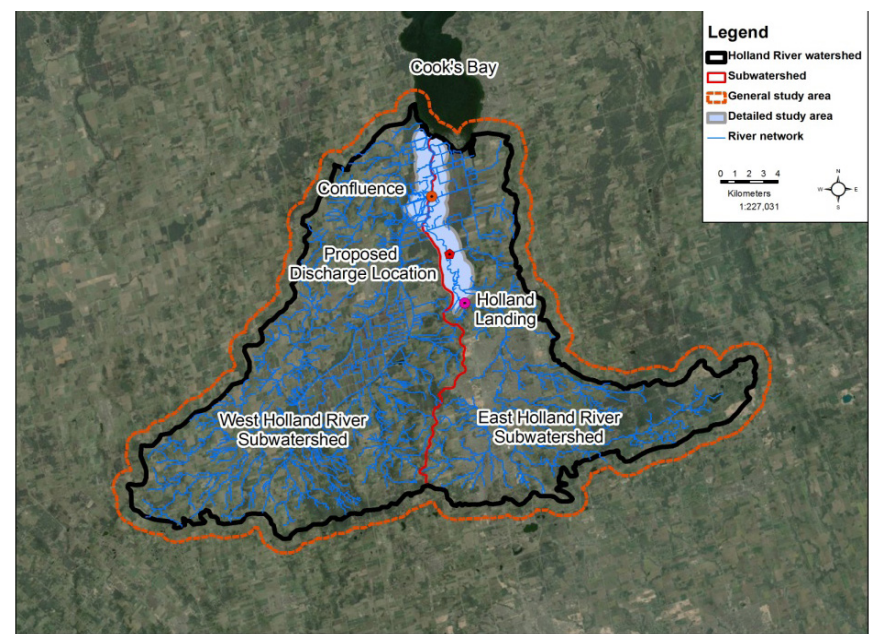

Figure 1 The study area.

The study area considered for the thermal study includes the lower portion of the East Holland River from Holland Landing to the confluence with the West Holland River, and the main branch of the Holland River to the confluence with Lake Simcoe (see Figure 1). This is the area potentially considered for the WRC discharge location and the area potentially affected by the WRC discharge. The West Holland River was not included in the detailed study area.

The broader more general study area considered for the thermal study includes the detailed study area and the East and West Holland River subwatersheds. This area was studied with the purpose of defining the hydro-meteorological inputs required for modelling the detailed study area. The general study area is outlined on Figure 1.

For the purposes of this study, the lower portion of the East Holland River lying within the study area limits and the main branch of the Holland River will be, for simplicity, referred to as the East Holland River.

\section{Approach}

The potential effects of the WRC discharge on the thermal and ice regimes of the East Holland River were studied and evaluated by utilizing an advanced dynamic numerical modelling approach. Thermal and river ice hydrodynamic models were built for the study area and the effects of the WRC discharge evaluated by comparing the results of the models generated by scenarios with and without the WRC discharge.

The EFDC model was built to study the thermal effects of the WRC discharge on the East Holland River. EFDC is a stateof-the-art hydrodynamic model capable of simulating aquatic systems (rivers, lakes, estuaries, reservoirs, wetlands and coastal regions) in one, two and three dimensions (1D, 2D and 3D) including flow, transport and biogeochemical processes. The model was originally developed by Virginia Institute of Marine Science, and is currently being supported by the U.S. Environmental Protection Agency (USEPA). Within the past two decades, EFDC has become one of the most widely applied and technically defensible hydrodynamic models in the world (Tetra Tech Inc. 2007). The model has been extensively tested, documented and applied worldwide by universities, governmental agencies and environmental consulting firms.

The CE-QUAL-W2 model was built to study the effects of the WRC discharge on river ice conditions in the East Holland River. CE-QUAL-W2 is a 2D water quality and hydrodynamic model, which can simulate ice processes including ice formation, growth, decay, and break for various waterbodies such as rivers, estuaries, lakes, reservoirs and river basin systems. CE-QUAL-W2 has been under continuous development since 1975. The original model was known as LARM (Laterally Averaged Reservoir Model) and was developed by Edinger and Buchak (1975). The current model release has been developed under research contracts between the U.S. Army Corps of Engineers and Portland State University under supervision of Dr. Scott Wells. The latest version (at the time of writing this paper) is 3.7.1, released on November 5, 2012. The model has been extensively applied worldwide in more than 116 countries, andin over 280 river systems. In Canada, the model has been applied to the Athabasca River, Battle River, Bow River, Bridge River and others (Portland State University 2012). 
Both temporal and spatial aspects of the thermal and river ice regimes in the East Holland River were analyzed and evaluated in this study. The temporal aspect was evaluated at several representative locations in the river downstream of the proposed discharge location on Queensville Sideroad. The spatial aspect was evaluated for selected days representing typical and extreme thermal and river ice conditions in the river.

\section{Data}

EFDC and CE-QUAL-W2 are data intensive models. The required inputs include hydrological parameters (flow rates, water levels, water temperatures), meteorological parameters (wind speed and direction, air temperature, dew point, atmospheric pressure, relative humidity, precipitation, global solar radiation and cloud cover) and effluent characterization (discharge rate, effluent water quality). These parameters were compiled as the models' boundary conditions from various monitoring stations shown in Figure 2.

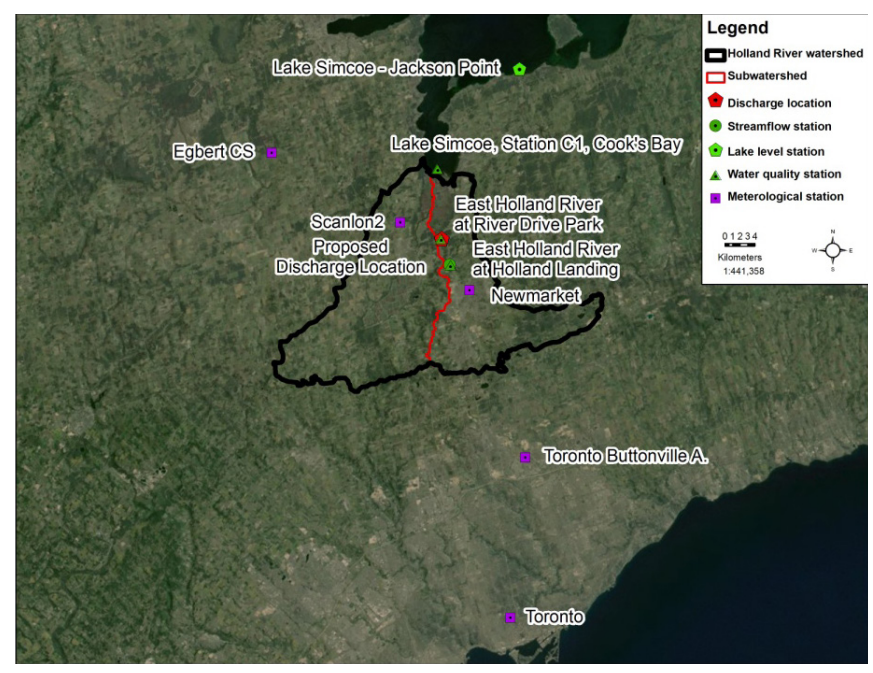

Figure 2 EFDC and CE-QUAL-W2 model data source locations.

The period from October 1, 2010 to March 31, 2012 was selected as the simulation period for the modelling. This period represents recent hydro-climatic conditions in the study area and is representative of typical hydrologic conditions in the East Holland River. The period was extended to March 2012 to cover two winter periods, as winter is the period of main concern for studying river ice processes.

There were limited water temperature and ice thickness data available for the East Holland River. Hence the objective of the modelling was to evaluate the trends in the relative differences between the model results (e.g. the change in estimated ice thickness or change in water temperature) rather than their absolute values. A field monitoring program has also been established to collect additional data for model calibration and validation.

\section{Model Setup}

EFDC_Explorer 6.0, developed by Dynamic Solutions-International LLC (DSI), was used in this study to build and execute the EFDC model. EFDC_Explorer is a graphical user interface (for Windows) to EFDC which streamlines model pre-processing, execution and post-processing, and extends EFDC by adding more functionality, such as parallel computing, to significantly speed up simulation.

Two types of modelling grid are supported in the EFDC model: curvilinear grid (quadrilateral shape) and Cartesian grid (square shape). Curvilinear grid can represent well curved and bent shorelines, which is the case in this study area. The Cartesian grid can also approach curved shorelines with very small cell size but this greatly increases model computational time. Thus, the curvilinear grid was selected.

The utility RGFGRID, distributed with Delft3D, was used to create and modify the curvilinear grid. Two steps are required to generate the curvilinear grid with RGFGRID: create splines, which form the shoreline boundary; and set the number of cells desired in the model domain, defined by four splines. The EFDC model grid built for the study area has 1028 cells, and the cell areas vary from $31 \mathrm{~m}^{2}$ to $14019 \mathrm{~m}^{2}$, with an average cell size of $1639 \mathrm{~m}^{2}$. Vertically, each cell was divided into two layers of equal height. The river bathymetry data were imported into EFDC_Explorer and interpolated with the option Average all Z's in Cell to assign bottom elevations to the grid cells.

The CE-QUAL-W2 model divides longitudinal model domain direction into segments and vertical direction into layers. A model segment is characterized by its length and orientation, and a vertical layer has properties of width and heights. Various layers can have different heights. The model does not calculate widths from common bathymetry properties (e.g. $x, y$, and $z$ data) by itself; external tools are required to calculate the width information. There are no software packages in public domain that could be used for grid generation; and due to the rapid updating of CE-QUAL-W2, commercial software packages do not support the most recent CE-QUAL-W2 version (version 3.7.1). Consequently, a utility to generate bathymetry and export model data to shape file for spatial view was developed in ArcMap 9.3.1 with VBA. The in-house utility can calculate widths using river bank geometry and underlying DEM data, and export the time series files for each CE-QUAL-W2 segment into a shape file for spatial display.

The CE-QUAL-W2 model grid built for the study area has 383 cells, and the cell areas vary from $43 \mathrm{~m}^{2}$ to $36614 \mathrm{~m}^{2}$ with average cell size $4195 \mathrm{~m}^{2}$.The elevations of the segments from the very bottom to the very surface section are within the range of $216 \mathrm{~m}$ to $222 \mathrm{~m}$. Each vertical layer is set to the same height of $0.25 \mathrm{~m}$, resulting in 23 active layers; with two dummy layers one on the top and the other at the bottom, as required in CE-QUALW2 bathymetry file format specification, resulting in 25 total vertical layers. 


\section{Calibration and Validation}

Conestoga-Rovers \& Associates (CRA) collected water level, flow velocity, and water temperature data at various locations in the river on December 1 and December 8, 2011. The December 1, 2011 event was used for model calibration and the December 8, 2011 event for model validation. To further validate the calibrated EFDC model performance CRA established continuous water temperature monitoring program in the East Holland River near the proposed discharge location from April2012. Additionally, to calibrate the CE-QUAL-W2 model CRA monitored ice thickness at three locations in the East Holland River downstream of the proposed discharge location during the 2012-2013 winter.

Table 1 summarizes the statistical performance of the EFDC model in simulating the water surface elevations for the calibration and validation events. The performance measures are very good for both events, with zero mean relative errors, and small mean absolute errors. The model had small positive bias for both the calibration and validation events. The validation measures are slightly worse than the calibration measures.

Table 1 Calibrated EFDC model performance in simulating water surface elevations.

\begin{tabular}{lcc}
\hline \multicolumn{1}{c}{ Performance Measure } & $\begin{array}{c}\text { Calibration } \\
(20111201)\end{array}$ & $\begin{array}{c}\text { Validation } \\
(20111208)\end{array}$ \\
\hline Maximum Absolute Error $(\mathrm{m})$ & 0.054 & 0.061 \\
Mean Absolute Error $(\mathrm{m})$ & 0.023 & 0.032 \\
Bias $(\mathrm{m})$ & 0.013 & 0.032 \\
Root Mean Square Error (m) & 0.027 & 0.037 \\
Mean Relative Error $(-)$ & 0.000 & 0.000 \\
\hline
\end{tabular}

Table 2 summarizes the statistical performance of the EFDC model in simulating the flow velocities for the calibration and validation events. The validation measures are actually better than the calibration measures. The model produced almost unbiased results for the validation event. The mean absolute error was $0.078 \mathrm{~m} / \mathrm{s}$ for the calibration event and only $0.041 \mathrm{~m} / \mathrm{s}$ for the validation event.

Table 2 Calibrated EFDC model performance in simulating horizontal velocity.

\begin{tabular}{lcc}
\hline \multicolumn{1}{c}{ Performance Measure } & $\begin{array}{c}\text { Calibration } \\
(20111201)\end{array}$ & $\begin{array}{c}\text { Validation } \\
(20111208)\end{array}$ \\
\hline Maximum Absolute Error $(\mathrm{m} / \mathrm{s})$ & 0.188 & 0.100 \\
Mean Absolute Error $(\mathrm{m} / \mathrm{s})$ & 0.078 & 0.041 \\
Bias $(\mathrm{m} / \mathrm{s})$ & -0.070 & -0.031 \\
Root Mean Square Error $(\mathrm{m} / \mathrm{s})$ & 0.099 & 0.048 \\
Mean Relative Error $(-)$ & -0.202 & -0.039 \\
\hline
\end{tabular}

Table 3 summarizes the statistical performance of the EFDC model in simulating the water temperature for the calibration and validation events. The performance measures are good for the calibration event, with very small maximum error and bias.
The validation measures are not very good due to the poor match of the model on two observations.

Table 3 Calibrated EFDC model performance in simulating water temperature.

\begin{tabular}{lcc}
\hline \multicolumn{1}{c}{ Performance Measure } & $\begin{array}{c}\text { Calibration } \\
(20111201)\end{array}$ & $\begin{array}{c}\text { Validation } \\
(20111208)\end{array}$ \\
\hline Maximum Absolute Error $\left({ }^{\circ} \mathrm{C}\right)$ & 0.9 & 2.0 \\
Mean Absolute Error $\left({ }^{\circ} \mathrm{C}\right)$ & 0.3 & 0.8 \\
Bias $\left({ }^{\circ} \mathrm{C}\right)$ & 0.1 & -0.7 \\
Root Mean Square Error $\left({ }^{\circ} \mathrm{C}\right)$ & 0.4 & 1.0 \\
Mean Relative Error $(-)$ & 0.0 & -0.2 \\
\hline
\end{tabular}

The calibration and validation water temperature data were collected during the mild 2011-2012 winter. Therefore, the EFDC simulation period was extended to March 31, 2013, and the model further validated with the hourly data from the continuous monitoring program. The model matched the data very well; the coefficient of determination for the extended validation period was 0.99 .

Table 4 summarizes the statistical performance of the CEQUAL-W2 model in simulating the water surface elevations for the calibration and validation events. The performance measures are very good for both events, with zero mean relative errors, and small mean absolute errors. The validation measures are slightly worse than the calibration measures.

Table 4 Calibrated and validated CE-QUAL-W2 model performance in simulating water surface elevations.

\begin{tabular}{lcc}
\hline \multicolumn{1}{c}{ Performance Measure } & $\begin{array}{c}\text { Calibration } \\
(2011 \text { 12 01) }\end{array}$ & $\begin{array}{c}\text { Validation } \\
(20111208)\end{array}$ \\
\hline Maximum Absolute Error $(\mathrm{m})$ & 0.051 & 0.050 \\
Mean Absolute Error $(\mathrm{m})$ & 0.023 & 0.024 \\
Bias $(\mathrm{m})$ & -0.014 & 0.024 \\
Root Mean Square Error $(\mathrm{m})$ & 0.027 & 0.030 \\
Mean Relative Error $(-)$ & 0.000 & 0.000 \\
\hline
\end{tabular}

Table 5 summarizes the statistical performance of the CEQUAL-W2 model in simulating the flow velocities for the calibration and validation events. The calibration results are better than the validation results except for the maximum absolute error. The mean absolute error was $0.099 \mathrm{~m} / \mathrm{s}$ for the calibration event and only $0.029 \mathrm{~m} / \mathrm{s}$ for the validation event.

Table 5 Calibrated CE-QUAL-W2 model performance in simulating horizontal velocity.

\begin{tabular}{lcc}
\hline \multicolumn{1}{c}{ Performance Measure } & $\begin{array}{c}\text { Calibration } \\
(20111201)\end{array}$ & $\begin{array}{c}\text { Validation } \\
(20111208)\end{array}$ \\
\hline Maximum Absolute Error (m/s) & 0.248 & 0.070 \\
Mean Absolute Error $(\mathrm{m} / \mathrm{s})$ & 0.099 & 0.029 \\
Bias $(\mathrm{m} / \mathrm{s})$ & -0.098 & -0.027 \\
Root Mean Square Error $(\mathrm{m} / \mathrm{s})$ & 0.122 & 0.038 \\
Mean Relative Error $(-)$ & -0.368 & -0.192 \\
\hline
\end{tabular}


Table 6 summarizes the statistical performance of the CEQUAL-W2 model in simulating the water temperature for the calibration and validation events. The performance measures are good for the calibration event, with small maximum absolute error and bias. The validation measures are not very good, with maximum absolute error $1.9^{\circ} \mathrm{C}$. It was found that two observation points had maximum discrepancy $1.7^{\circ} \mathrm{C}$ and $1.9^{\circ} \mathrm{C}$ which significantly impacted the validation performance measures.

Table 6 Calibrated CE-QUAL-W2 model performance in simulating water temperature.

\begin{tabular}{lcc}
\hline \multicolumn{1}{c}{ Performance Measure } & $\begin{array}{c}\text { Calibration } \\
(20111201)\end{array}$ & $\begin{array}{c}\text { Validation } \\
(20111208)\end{array}$ \\
\hline Maximum Absolute Error $\left({ }^{\circ} \mathrm{C}\right)$ & 1.0 & 1.9 \\
Mean Absolute Error $\left({ }^{\circ} \mathrm{C}\right)$ & 0.4 & 0.7 \\
Bias $\left({ }^{\circ} \mathrm{C}\right)$ & -0.3 & -0.7 \\
Root Mean Square Error $\left({ }^{\circ} \mathrm{C}\right)$ & 0.5 & 0.9 \\
Mean Relative Error $(-)$ & -0.1 & -0.2 \\
\hline
\end{tabular}

Table 7 summarizes the statistical performance of the model in simulating ice thickness. The performance measures are good with high coefficient of determination of 0.8 , low bias and mean absolute error. The maximum absolute error of $0.132 \mathrm{~m}$ occurred at the monitoring location downstream of the confluence, which is attributed to the effect of the West Holland River water temperature boundary.

Table 7 Calibrated CEQUALW2 Model Performance in simulating ice thickness.

\begin{tabular}{lc}
\hline \multicolumn{1}{c}{ Performance Measure } & Calibration (2012 and 2013) \\
\hline Maximum Absolute Error (m) & 0.132 \\
Mean Absolute Error $(\mathrm{m})$ & 0.04 \\
Bias (m) & 0.009 \\
Root Mean Square Error $(\mathrm{m})$ & 0.058 \\
Mean Relative Error & $*$ \\
Coefficient of Determination & 0.8 \\
* not available due to the existence of zero ice thickness observation.
\end{tabular}

\section{Results}

The EFDC and CE-QUAL-W2 models produce results that are distributed in time and space. The models' results are therefore presented as time-varying comparison of water temperatures and ice thicknesses without and with the WRC discharge, at different locations downstream of the WRC discharge, as well as spatial snapshots of the study area at different times of the year.

The time-varying comparison of water temperatures and ice thicknesses without and with the WRC discharge was constructed at eight locations downstream of the WRC discharge (50 m, $100 \mathrm{~m}, 250 \mathrm{~m}, 500 \mathrm{~m}, 1000 \mathrm{~m}$ and $2500 \mathrm{~m}$ downstream of Queensville Sideroad, $250 \mathrm{~m}$ downstream of the East Holland River and West Holland River confluence, and at the mouth of the river in Lake Simcoe). The eight locations used are shown on Figure 3.

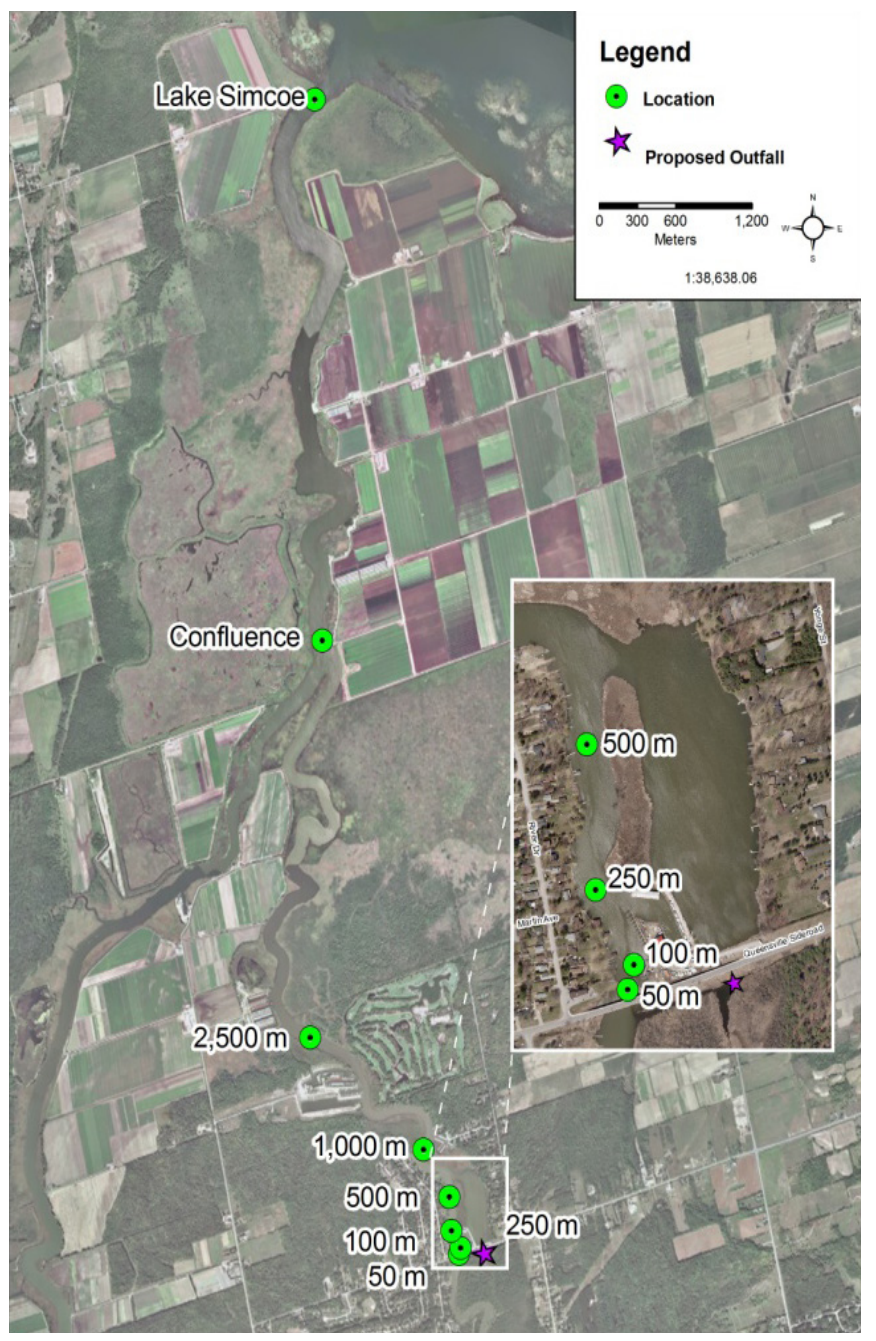

Figure 3 Locations for the temporal evaluation of model results.

\subsection{EFDC}

Table 8 summarizes the mean, maximum and minimum water temperature changes from the baseline scenario (without the WRC discharge). Two winter periods (the winters of 2010-2011 and 2011-2012) and one summer period (2011) were investigated in particular, as the WRC effects are expected to be most pronounced during the winter and summer.

Table 8 Water temperature changes $\left(\right.$ in ${ }^{\circ} \mathrm{C}$ ) due to the WRC discharge at Queensville.

\begin{tabular}{cccccccccc}
\hline Period & Stat. & $50 \mathrm{~m}$ & $100 \mathrm{~m}$ & $250 \mathrm{~m}$ & $500 \mathrm{~m}$ & $1000 \mathrm{~m}$ & $2500 \mathrm{~m}$ & $\begin{array}{c}\text { Conflu- } \\
\text { ence }\end{array}$ & $\begin{array}{c}\text { Lake } \\
\text { Simcoe }\end{array}$ \\
\hline $20101101-$ & Mean & 2.9 & 3.1 & 2.7 & 2.6 & 2.0 & 0.9 & 0.1 & 0.0 \\
20110331 & Max & 5.7 & 5.8 & 4.7 & 4.7 & 4.0 & 2.9 & 0.8 & 0.4 \\
$20110701-$ & Mean & -2.7 & -2.7 & -2.7 & -2.5 & -1.7 & -0.9 & 0.0 & 0.0 \\
20110831 & Max & -7.3 & -6.8 & -6.1 & -5.7 & -3.6 & -2.0 & -0.3 & -0.5 \\
$20111101-$ & Mean & 2.2 & 2.4 & 2.1 & 2.1 & 1.8 & 1.1 & 0.1 & 0.0 \\
20120331 & Max & 4.8 & 5.0 & 4.3 & 4.3 & 3.6 & 2.5 & 0.8 & 0.8 \\
\hline
\end{tabular}


The results in Table 8 show that in general the maximum differences in water temperature occur immediately downstream of the discharge location. Furthermore, the maximum change in the ambient water temperature was obtained in the summer period $\left(-7.3^{\circ} \mathrm{C}\right)$. The maximum change during the winter periods was slightly lower: $5.7^{\circ} \mathrm{C}$ for the first winter period (2010-2011) and $4.8^{\circ} \mathrm{C}$ for the second winter period (2011-2012). The mean changes in water temperature are much smaller than the maximum changes; $-2.7^{\circ} \mathrm{C}$ for the summer period and $2.4^{\circ} \mathrm{C}$ to $3.1^{\circ} \mathrm{C}$ for the two winter periods respectively.

For some scenarios summarized in Table 8 the change in water temperature is larger $100 \mathrm{~m}$ downstream of the discharge location as opposed to $50 \mathrm{~m}$ downstream. This is explained by the progression of the thermal plume in the river which is not always fully mixed with the ambient water in the river at the $50 \mathrm{~m}$ location. Depending on the hydrodynamic conditions, the plume can be very attached to the right bank of the river (during high flows) or can even travel upstream (during low flows or high lake levels).

Figure 4 shows the monthly water temperature changes at different locations due to the WRC discharge to the river. The

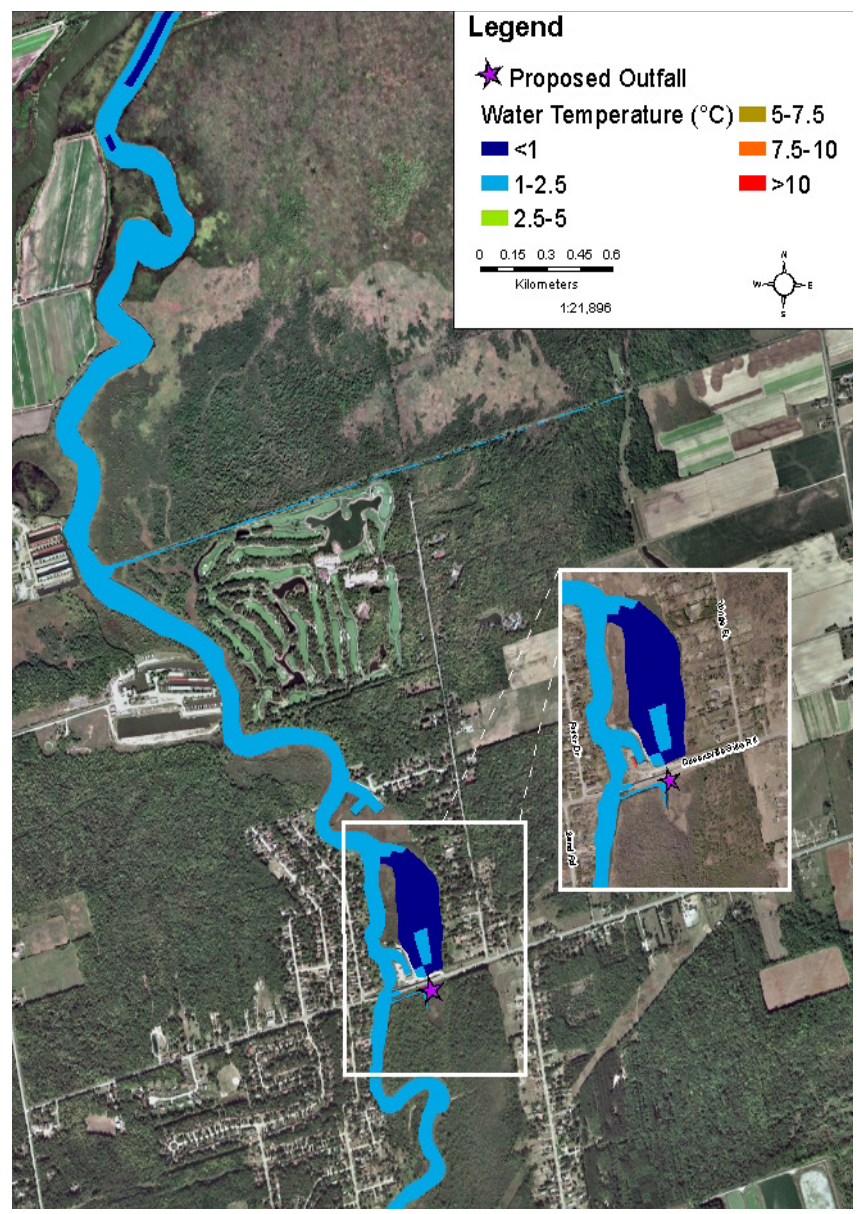

Figure 5 Spatial distribution of water temperatures in the East Holland River for the scenario Mean Winter Water Temperature Increase without the WRC discharge. results suggest that the changes in water temperature decrease moving downstream; near the confluence with the West Holland River, the changes in water temperature are very small.

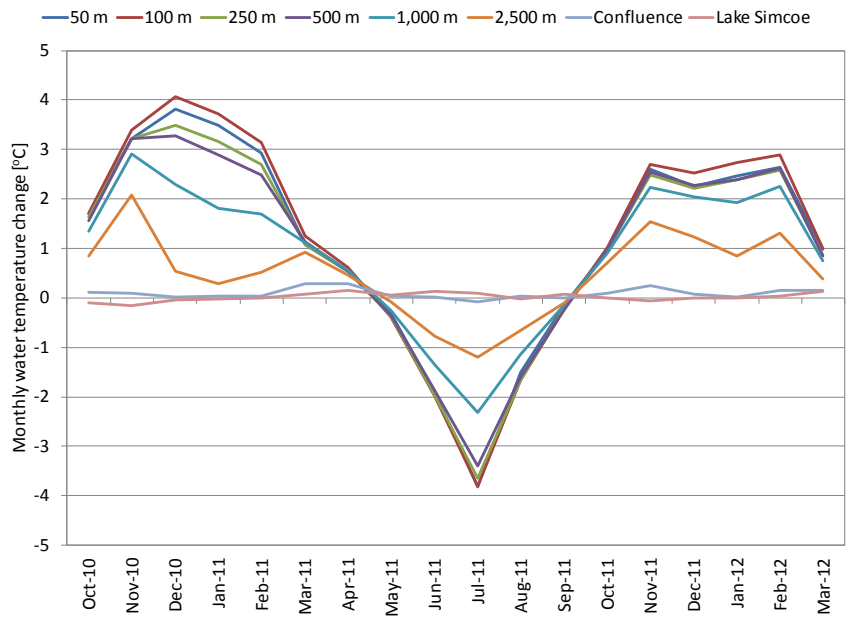

Figure 4 Changes in mean monthly temperatures in the East Holland River as a result of the WRC discharge.

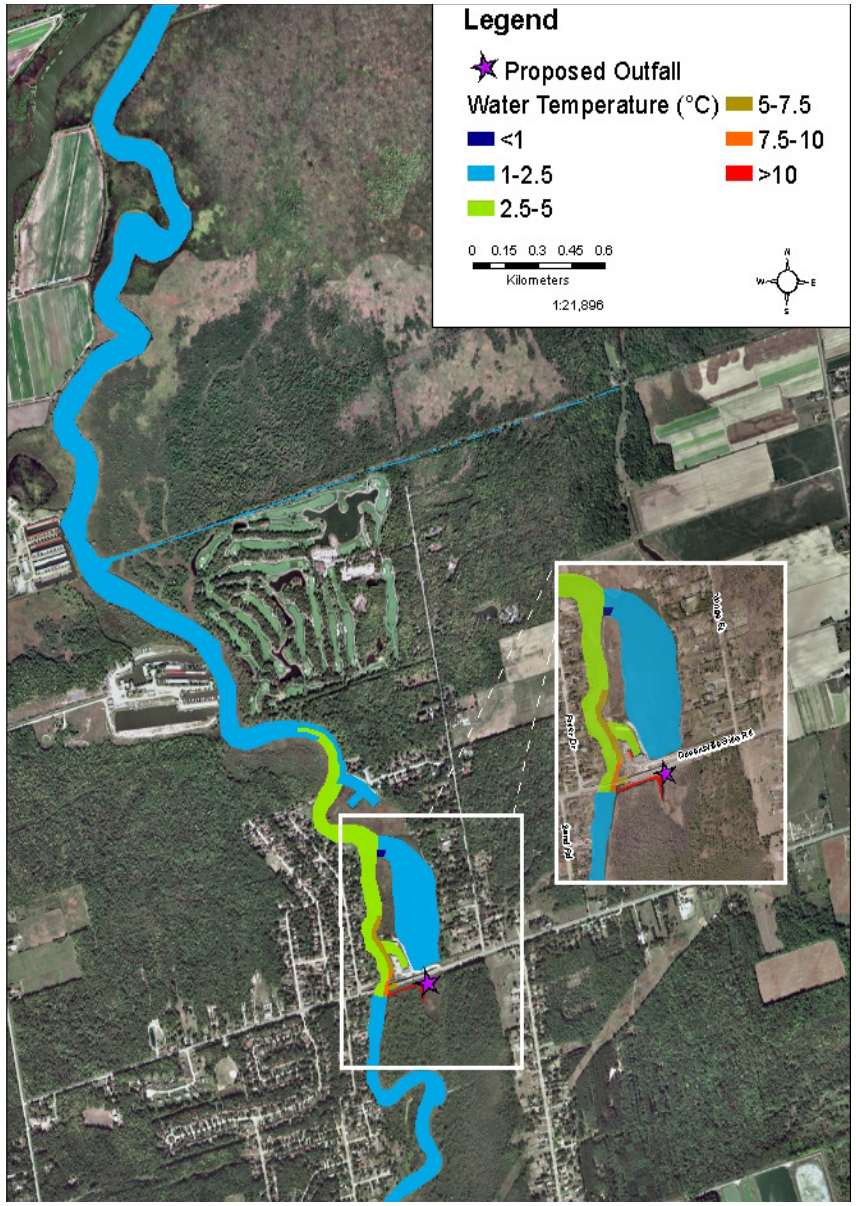

Figure 6 Spatial distribution of water temperatures in the East Holland River for the scenario Mean Winter Water Temperature Increase with the WRC discharge. 
Different scenarios (representative dates) were defined for studying the changes in the spatial distribution of water temperatures in the East Holland River. The scenarios were defined based on the average, maximum and minimum differences in water temperatures at the eight locations discussed in the previous section. Only the mean winter water temperature increase (Winter mean) scenario is discussed here, but the results for all scenarios can be found in CRA et al. 2013.

Figures 5 and 6 show the water temperature for the scenario Winter mean. Without the WRC discharge (Figure 5), water temperatures in the river are within the range of $0{ }^{\circ} \mathrm{C}$ to $2.5^{\circ} \mathrm{C}$. When the WRC effluent $\left(11^{\circ} \mathrm{C}\right.$ in March) is discharged to the river (Figure $6)$, water temperatures in the river in the vicinity of the discharge location increase from $1.3^{\circ} \mathrm{C}$ to $7.5^{\circ} \mathrm{C}$. The thermal plume can be traced for about $1.5 \mathrm{~km}$ downstream of the discharge location.

\subsection{CE-QUAL-W2}

Figure 7 show that the first $1000 \mathrm{~m}$ of the river downstream of the discharge location are most affected by the WRC discharge; the next $2000 \mathrm{~m}$ is a section in the river where the magnitude of the WRC effects is modelled to sharply decrease; and the last section of the river from the confluence to Lake Simcoe is minimally affected by the WRC discharge.

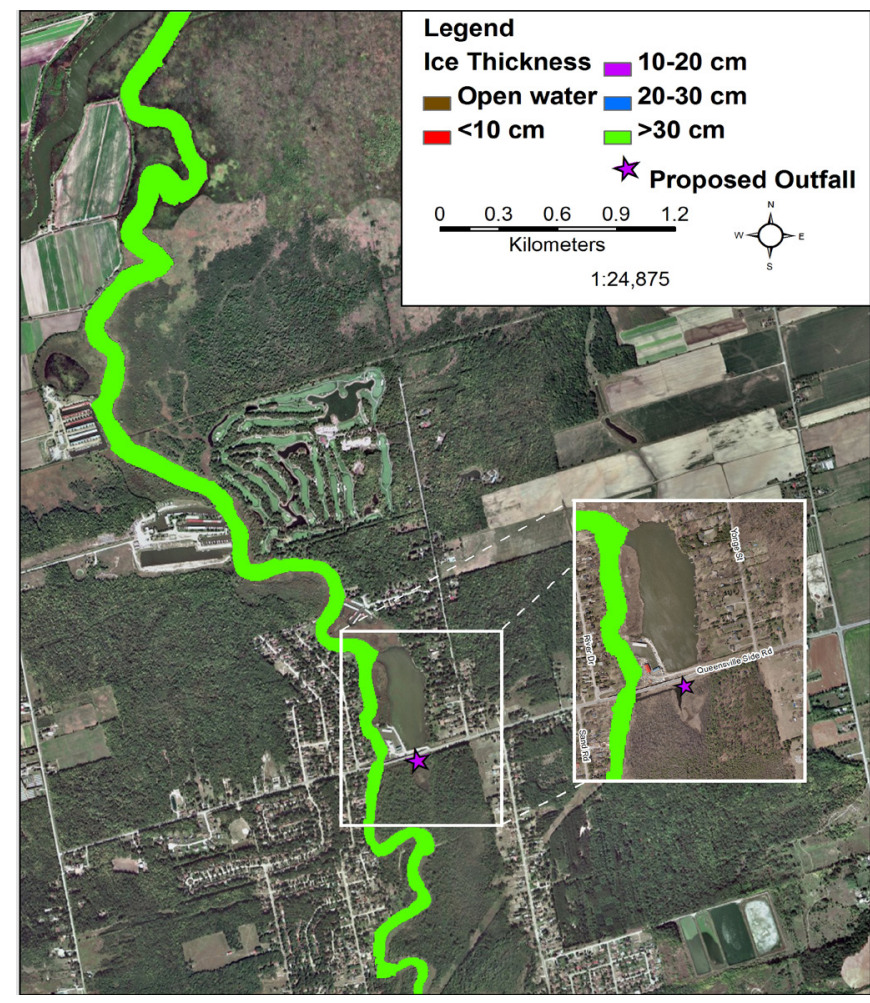

Figure 8 Spatial distribution of ice thickness in the East Holland River for the winter 2010-2011 scenario Average Ice Thickness without the WRC discharge.

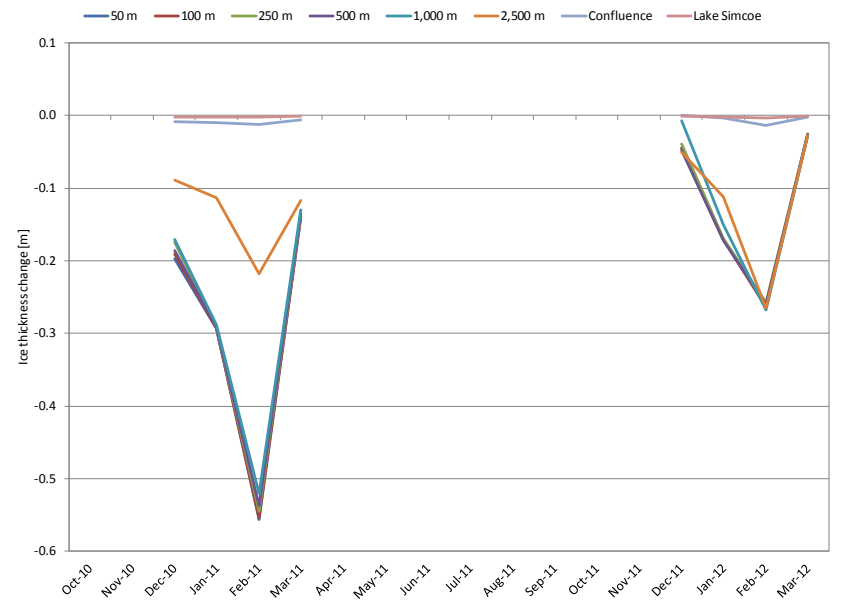

Figure 7 Changes in mean monthly ice thickness in the East Holland River as a result of the WRC discharge.

Different scenarios were defined for studying the changes in the spatial distribution of ice thickness in the East Holland River. The scenarios were defined based on the maximum and average differences in ice thickness at the location 2500 m downstream of the discharge location in the river. Only the Average Ice Thickness for the 2010-2011 winter scenario is discussed here, but the results for all scenarios can be found in CRA et al. 2013.

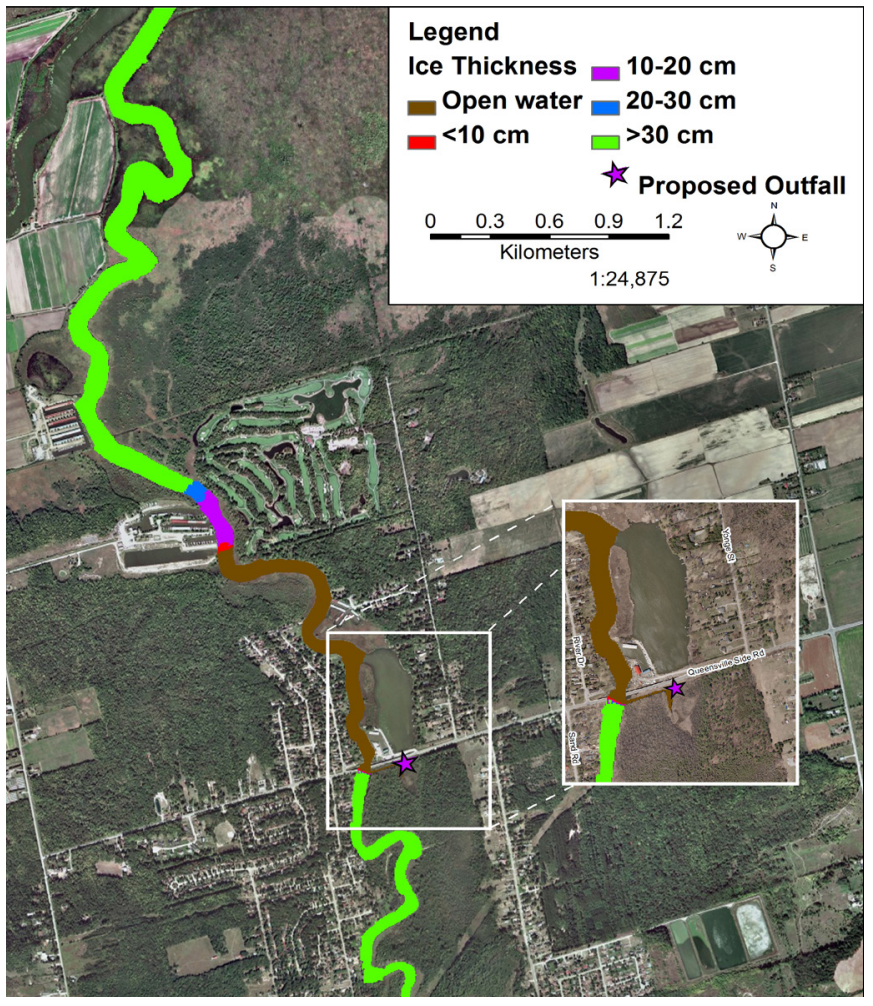

Figure 9 Spatial distribution of ice thickness in the East Holland River for the winter 2010-2011 scenario Average Ice Thickness with the WRC discharge. 
Figures 8 and 9 show the spatial distribution of ice thickness for the Average Ice Thickness scenario without and with the WRC discharge for the 2010-2011 winter. Without the WRC discharge (Figure 8), the ice thickness on the average day (February 7,2011 ) is above $30 \mathrm{~cm}$ in the river. For the scenario with the WRC discharge (Figure 9), the ice thickness will be reduced to zero for a distance $1.8 \mathrm{~km}$ downstream of the discharge location; to less than $10 \mathrm{~cm}$ for a distance $1.9 \mathrm{~km}$ downstream; to less than $20 \mathrm{~cm}$ for a distance of $2.1 \mathrm{~km}$ downstream; and to less than $30 \mathrm{~cm}$ for a distance of $2.2 \mathrm{~km}$ downstream. Downstream of the confluence there will be no change in ice thickness in the river.

For the purposes of this study, the ice duration is defined from the date of ice formation (with ice thicker than $\sim 1 \mathrm{~cm}$ ) to the date of ice break (with ice thickness $<1 \mathrm{~cm}$ ) for each winter period. Without the WRC discharge, the model predicted longer ice durations for the 2010-2011 winter than for the 2011-2012 winter, since 2010-2011 was a much colder winter.

With the WRC discharge, the locations $50 \mathrm{~m}, 100 \mathrm{~m}, 250 \mathrm{~m}$, $500 \mathrm{~m}$, and $1000 \mathrm{~m}$ downstream of the discharge location are to be ice-free; at the river location $2500 \mathrm{~m}$ downstream of the discharge point, both the mean ice thickness and durations are to be reduced; and downstream of the confluence the mean ice thickness and ice cover duration will be minimally affected by the WRC discharge.

The ice duration is expected to be shortened by the WRC discharge. For example, in the winter of 2010-2011, at the location $2500 \mathrm{~m}$ downstream of the discharge location, the ice duration was modelled to be reduced by about $7 \mathrm{~d}$, from $94 \mathrm{~d}$ to $87 \mathrm{~d}$. At the confluence of the East Holland and West Holland Rivers the ice duration is modelled to be reduced by $2 \mathrm{~d}$.

\section{Summary}

Two hydrodynamic models using EFDC and CE-QUAL-W2 were built to study the thermal effects due to the WRC discharge at Queensville Sideroad. The EFDC model predicted that the WRC discharge will increase water temperature during winter and decrease it during summer, and have minimal effects in spring and fall since the effluent temperatures are close to the ambient river temperature. The discharge will have a moderating effect on water temperatures during the summer when the river experi-

\section{Hailiang Shen Conestoga-Rovers \& Associates, Waterloo,} Ontario.

Juraj Cunderlik Conestoga-Rovers \& Associates, Waterloo, Ontario.

\section{George Godin Conestoga-Rovers \& Associates, Waterloo,} Ontario. ences low flow and high water temperatures. Spatially, the water temperature effect of the WRC discharge will be the maximum near the discharge location, diminishing downstream of the discharge location, and minimal downstream of the confluence of the West Holland and East Holland Rivers.

Ice thickness in the River is modelled to decrease during the winter period. The areas near the discharge location will experience the largest decrease in ice thickness, and the effect of the WRC discharge on ice thickness is modelled to gradually diminish downstream of the discharge location. Ice duration is modelled to be shortened by the WRC discharge.

Because of the uncertainties in the absolute values (e.g. ice thickness on a particular day in a particular location in the river) predicted by the EFDC and CE-QUAL-W2 models, it is recommended to consider the trends in the relative differences between the model scenarios presented in this study (e.g. the change in estimated ice thickness or change in water temperature) rather than to the absolute values. The differences between two predictions should provide reasonable estimate of the relative change (or effect) that can be attributed to the WRC discharge.

\section{References}

Cole, T. M. and S. A. Wells. 2011. CE-QUAL-W2: A Two-Dimensional, Laterally Averaged, Hydrodynamic and Water Quality Model, Version 3.71 User Manual. Portland, OR: Portland State University.

CRA (Conestoga-Rovers \& Associates), AECOM and Black \& Veatch. 2013. Upper York Sewage Solutions Environmental Assessment, Thermal Effects of the Water Reclamation Centre Discharge on the East Holland River. Prepared for The Regional Municipality of York.

Edinger, J. E. and E. M. Buchak. 1975. A Hydrodynamic and Two-dimensional Reservoir Model: The Computational Basis. Cincinnati, OH: U.S. Army Engineer Division, Ohio River. (Contract DACW27-74-C-0200.)

Portland State University. 2012. CE-QUAL-W2 Hydrodynamic and Water Quality Model. http://www.ce.pdx.edu/w2/.

Tetra Tech Inc. 2007. The Environmental Fluid Dynamics Code User Manual USEPA Version 1.01. Fairfax, VA: Tetra Tech, Inc.

Adrian Coombs The Regional Municipality of York, Newmarket, Ontario.

Alan Rimer Black \& Veatch, Markham, Ontario

Ian Dobrindt Conestoga-Rovers \& Associates, Newmarket, Ontario. 